\title{
A VECM Approach Towards the Effect of Bank Credit on Economic Growth: Empirical Evidence for Nigeria
}

\author{
Akinwale, Samson Olusegun, PhD \\ Obagunwa, Oluwabusayo Temitope, \\ Department of Banking and Finance, \\ Adekunle Ajasin University Akungba-Akoko, Ondo State, Nigeria
}

Doi:10.19044/esj.2019.v15n19p52～느:http://dx.doi.org/10.19044/esj.2019.v15n19p52

\begin{abstract}
Despite policy reforms to enhance the performance of commercial banks and their contributions to economic growth, little has been achieved in the economy. This is due to the country still experiencing low domestic investment, high unemployment rate, and escalating poverty resulting from lack of adequate credits required for investment and production activities in the economy. The study investigated the effect of bank credit on economic growth in Nigeria by using secondary data from Central Bank of Nigeria (CBN) Statistical Bulletin covering the period of 1981 to 2017. The study employed Augmented Dickey - Fuller (ADF), Johansen C-integration, Error Correction Model, and Pairwise Granger Causality Techniques. The result ADF indicated that credit to manufacturing sector (CMS), agricultural sector (ACS), general commerce (CGC), and real gross domestic product (RGDP) were stationary at first difference order of integration. On the other hand, the Johansen Co-integration test revealed that there is a long-run relationship among the variables. The result of the Error Correction Model revealed that CMS and ACS simulate RGPS while CGC negatively influenced economic growth in Nigeria. Also, CMS and ACS granger did not cause RGDP, but CGS granger caused RGDP. The study concluded that bank credit to different sectors of the economy plays significant role in promoting economic growth in Nigeria. The study recommended that banks should ensure more credits flow to the manufacturing sector and agricultural sector in order to ensure bidirectional relationship between bank sectoral credit and economic growth.
\end{abstract}

Keywords: Bank Credit, Error Correction Model, Economic Growth, Finance 


\section{Introduction}

The financial system of an economy plays a catalytic role in the development of an economy. However, in the financial system, commercial banks remain one of the major contributors to growth through the intermediation and channeling of funds among economic agents in the economy (Marshal, Solomon \& Onyekachi, 2015).

Deposit money banks are institutions that collect deposits, grant credits, and render other financial services for profit purposes. Akujuobi and Nwezeaku (2015) asserted that deposit money banks perform the role of accepting deposits, lending and safe keeping of valuables, as well as creating money through lending activities. Through their intermediation role, deposit money banks are able to encourage investments by providing the required financial resources from deposits. Odufuye (2017) opined that banks enhance investments through the identification and funding of viable business opportunities, mobilize idle savings, promote trade, provide mechanisms for hedging against risk, as well as facilitate the exchange of goods and services.

Banking lending remains one of the major important functions of banks in the economy. Access to bank credit strengthens productive assets by ensuring investment in productive sectors, education or health sector which have ripple effect on the growth of the economy (Anthony, 2012). Thus, bank credit promotes investments which in turn have a positive effect on economic growth. Adewole, Akinmulegun, Akinde, and Popoola (2018) argued that finance is prerequisite to investments and productive activities. Oluitan (2012) stated that early economists identified the role of bank credit in promoting investments through their intermediation function of mobilizing savings and their efficient allocation to the investment sector of the economy, which contributes to growth and development.

Economic growth refers to the improvement in the economic conditions of an economy. It is the continuous increase in the productive capacity of an economy and the ability to satisfy demand for goods and services, resulting from increased innovation and production scale over a particular period of time (Olowofeso, Adeleke \& Udoji, 2015). According to Bakare, Isaac, and Samuel (2015), economic growth is the positive change in the production level of goods and services and significant improvement of a country over a certain period of time.

The linkage of the relationship between banking sector credit and economic growth has received the attention of authorities globally, and monetary authorities have continued to strive to ensure that the banking sector plays its major role of driver of the real sector via effective lending that promotes growth and development (Olowofeso et al., 2015). Theoretically, Schumpeter (1934), Goldsmith (1969), McKinnon (1973), and Shaw (1973) robustly stressed the role of banking sector development in promoting 
sustainable economic growth. It is widely believed that commercial bank credit is closely linked to economic output, and effective performance of banking lending is important for economic growth both in the short and long run (Obamuyi, Edun \& Kayode, 2011; Bakere et al., 2015; Akujuobi \& Nwezeaku, 2015). This is because through their intermediation role, banks are able to pool large volume of financial resources and channel them to value, thereby enhancing economic and productive activities which result to economic growth. Artelaris, Antonios, Mark, and Edwin (2007) argued that progressive growth in developing an economy relies on efficient pooling of domestic savings and foreign capital by banks for productive investments.

In Nigeria, the role of commercial banks has continued to increase due to the demand of bank services in the economy. The increasing role of banks in Nigeria could be traced to the period of pre-independence era when resources were needed for infrastructural and entrepreneurial development (Marshal et al., 2015). According to the Central Bank of Nigeria (2016), the banking sector, which has 24 commercial banks, registered improved performance with total assets of N28173.3 trillion and N31682.8 billion in 2015 and 2016 respectively with total loans and advances of N16,117 billion in 2016. The total deposits into the banks stood at N6180.0 billion in 2016 (CBN, 2016). However, over the years, banking credit has been on the increase and the effect of this credit has been felt by different sectors in the economy. Banking sector credit stood at N7,706.4 in 2010; N7,312.7 in 2011; N8,150.0 in 2012; N10,005.6 in 2013; N12,889.4 in 2014; N13,086.2 in 2015; and N16,117.2 in 2016 (CBN, 2016).

However, recognizing the active position of bank credit in an economy resulted in the adoption of diverse banking reforms and the Structural Adjustment Programme in 1986 by the Central Bank of Nigeria in order to deepen the banking sector in terms of savings mobilizing and increase credit accessibility to the real sector (Odufuye, 2017).

Despite the policy reforms, little has been achieved in the Nigerian economy as the country is still experiencing low domestic investment, high unemployment rate, and escalating poverty among others. These problems resulted from lack of adequate credits required for investment and production activities in the economy. Anthony (2012) cited lack of funds as the major impediment to investments in modern machines, information technology, and development of human resources which can produce effective and competitive performance. Odofuye (2017) traced low investments in the economy to the unwillingness of banks to provide credits to the industrial sector resulting from financial mismatch between short-term credit and medium to long-term funds needed by the industrial sector.

Abubakar and Gani (2013) stated that the real sectors are faced with the difficulty of accessing required financial resources especially from deposit 
money banks that hold about $90 \%$ of savings resulting from high-interest rate. According to Odofuye (2017), the concentration of deposit money banks in meeting the financing need of oil and gas, communication, general commerce sectors, and government is detrimental to real sectors such as agricultural, manufacturing, and mining.

However, there are diverse studies on the relationship between bank credit and economic growth. There seems to be inconclusive empirical findings as to the linkages between bank credit and economic growth. Akujuobi and Nwezeaku (2015); Marshal et al. (2015); Igyo, Simon and Lorlumun (2016) as well as Makinde (2016) concluded that there is significant relationship between bank credit and economic growth while Ekpenyong and Aecha (2011); Azeez and Oke (2012) and Odofuye (2017) found insignificant relationship between bank credit and economic growth. Furthermore, majority of the study conducted did not properly disaggregate bank sector credit and how they influence the economy. Similarly, the direction of causality between the disaggregated bank credit to different sectors and economic growth was not adequately documented. These revealing gaps are what this study set out to fill by examining the disaggregated effect of bank credit on the economic growth in Nigeria. The other parts of the paper are literature review, methodology, interpretation of data, and finally, conclusion and recommendations.

\section{Literature Review}

Bank credit involves contractual agreement between a bank and customer in which financial resources are made available to the customer in terms of credit with a promise to repay the credit at a future period with interest. According to John and Terhemba (2016), bank credit is the process of making money available to a customer based on some agreed terms with regards to repayment with interest. Ajayi (2000) noted that credit is a promise by one party to pay another for money borrowed or goods and services received. Banks are therefore debtors to the depositors of funds and creditors to the borrowers of funds (Ogunmuyiwa, Okunneye \& Amaefule, 2017).

Economic growth is the increase in the productive capacity of an economy. It is a sustained increase in the production of goods and services of a nation during a period of time. According to Ogbonna and Appah (2011), economic growth is a constant increase in per capita national output or net national product over a long period of time. The term economic growth is described as the positive and continuous increase in aggregate goods and services produced in an economy within a given period of time. The important measure of economic growth is gross domestic product which measures the monetary value of goods and services that are produced in the economy during a fiscal year. 
In China, Wang, Li, Abdou, and Ntim (2015) examined the relationship between financial development and economic growth. Ordinary Least Square (OLS) multiple regressions were applied on a set of data from China for the period 1978 to 2013 to determine the effects of financial development on economic growth. Results revealed that financial development had negative effects on economic growth in general, though on the growth of the tertiary industry in particular. Also, it was found that financial development has no significant effect on the primary and secondary industries.

Ono (2017) assessed the finance-growth nexus in Russia using vector auto regression model. The empirical analysis was divided into two major parts: 1999 through 2008 was named subperiod 1, while 2009 through 2014 was named subperiod 2. The first part of the analysis revealed that there is causality from economic growth to money supply and bank lending, which implies demand-following responses; while the second part of the empirical analysis revealed that economic growth granger causes bank lending although there is no causality from money supply to economic growth.

Mushtaq (2016) established the direction between banks' major activities and economic growth in Pakistan by employing Johansen test of Cointegration and Granger Causality on times series data from 1961 to 2013. The results showed that there is no co-integration or causal relationship between GDP growth and deposits in Banks of Pakistan while there exists short run and long run causality running from GDP growth to bank's lending activities.

Nwakanma, Nnamdi, and Omojefe (2014) evaluated the long-run relationship and the directions of prevailing causality between bank credits to the private sector and the nation's economic growth. The study concluded based on the Autoregressive Distributed Lag Bound (ARDL) and Granger Causality that bank credits have significant long-run relationship with growth but without significant causality in any direction. Ogege and Shiro (2013) in a study covering 1974 to 2010 used co-integration and error correction model, discovered a long-run relationship and concluded that commercial credits contribute positively to growth but is significant in the long run.

Obradovi and Grbic (2015) investigated the causal relationship between financial development of banks and economic growth in Serbia. The study employed quarterly data for the period Q1 2004-Q4 2011 which was evaluated using Toda-Yamamoto causality to test the direction of causality among real GDP growth rate, Ratio of bank credit to households to GDP, Ratio of bank credit to private enterprises to GDP, Ratio of bank credit to households to GDP, and Ratio of bank deposit liabilities to nominal GDP. It was revealed that there is a significant unidirectional causality that runs from both private enterprise credit to GDP and household credit to GDP to economic growth, 
while a bidirectional causality existed between the share of bank credit to the nonfinancial private sector in total domestic credit and economic growth rate.

Shittu (2012) examined the impact of financial intermediation on economic growth in Nigeria between 1970 and 2010 using the unit root test and co-integration test and the error correction model. The study found that financial intermediation notable deposit mobilization is significant in determining economic growth in Nigeria. Nwaru and Okorontah (2014) investigated bank credit versus output using multiple regression and it revealed that credit to the private sector is positive but insignificant and that real output causes financial development, but not vice versa.

Sipahutar, Oktaviani, Siregar, and Juanda (2016) explored the effect of credit on economic growth, unemployment, and poverty in Indonesia. The study employed Vector Auto-regression (VAR) and Error Correction Model (ECM) to examine the relationship between banks credit and annual GDP per capita growth rates, unemployment, and poverty. It was found that there exists a bidirectional causality between banks credit and economic growth.

Oluitan (2012) assessed the effect of bank credit on economic growth in Nigeria. It was found that oil export had negative effect on economic growth while non-oil export and bank credit had positive effect. Anthony (2012) investigated the determinants of bank savings in Nigeria as well as examined the impact of bank savings and bank credits on Nigeria's economic growth from 1970 to 2006 through the adoption of Distributed Lag-Error Correction Model (DL-ECM) and Distributed Model. The empirical results showed that there is positive relationship between GDP per capita, financial deepening, and interest rate spread, and more, a negative relationship between real interest rate and inflation rate and size of private domestic savings. Also it was discovered that total private savings, private sector credit, public sector credit, interest rate spread, and exchange had positive effect on economic growth.

Akpansung and Babalola (2012) examined the relationship between banking sector credit and economic growth in Nigeria over the period 19702008 using the two-stage least squares approach. It was found that private sector credit impacted positively on economic growth during the sample period while lending rate impeded economic growth. The study of Aliero, Abdullahi, and Adamu (2013) examined the relationship between the private sector and economic growth in Nigeria using autoregressive distributed lag (ARDL) approach and concluded that a long-run equilibrium relationship exists between private sector credit and economic growth. They found a significant relationship between the duo and recommended comprehensive policies and strong legal framework to facilitate the disbursement and recovery of private sector credit.

Olowofeso et al. (2015) examined the impacts of private sector credit on economic growth in Nigeria using the Gregory and Hansen (1996) co- 
integration test and fully modified ordinary least squares from 2000 to 2014. It was found that credit to private sector, government expenditure, and gross capital formation had positive effect on economic growth, while prime lending rate had negative and significant effect on economic growth in Nigeria. Akujuobi and Nwezeaku (2015) examined the effect of bank lending activities on economic development in Nigeria, covering the period 1980-2013, by employing two development proxy, namely, human development index and the industrial gross domestic product; while commercial bank credit to the general commerce, production, services, and other sectors formed components of bank lending activities and analysis using Ordinary Least Square (OLS) and Co-integration Techniques. It was revealed that model 1, both credit to the general commerce and production sectors, had significant effect on economic development while model 2 showed that only credit to the services sector had insignificant effect on economic development.

Adenugba (2012) investigated the impact of banking system credit on economic growth in Nigeria by employing time series data collected from the CBN Statistical Bulletin ranging from 1983 to 2012, analyzed using the Ordinary Least Square (OLS) technique, also, it was found that bank credit, money supply, and minimum rediscounted rate had positive and significant effect on economic growth while savings and exchange rate had negative and significant effect on economic growth.

Marshal et al. (2015) looked into the impact of bank domestic credits on the economic growth of Nigeria using time series data from 1980 to 2013. The study employed credit to private sector, credit to government sector, and contingent liability as proxy for bank domestic credit, while gross domestic product represented economic growth. The results of the study showed that credit to the private sector (CPS) and Credit to the government sector (CGS) had positive and significant effect on gross domestic product in the short run, while bank domestic credit had insignificant effect on gross domestic product in Nigeria in the long run.

Odufuye (2017) investigated the impact of bank credit on the Nigerian economy growth from 1992 to 2015 by employing gross domestic product as proxy for economic growth and commercial bank credits to small and medium scale enterprises, credits to private sector, money supply, and interest rate as for bank credit. And it was revealed that commercial bank credits to small and medium scale enterprises, credits to private sector, money supply, and interest rate had insignificant impact on gross domestic product while bank credit instruments jointly influenced gross domestic product. Adewole, Akinmulegun, Akinde, and Popoola (2018) examined the relationship between deposit money bank credit and economic growth in Nigeria based on secondary data from 2006 to 2015 using multiple regression analysis. And it was revealed in equation I that there exists a positive correlation between the 
dependent variable (Total Bank Credit) and independent variable (Cash Reserve Ratio, Liquidity Ratio, Deposit Rate, Lending Rate), while the result of equation II indicated that there exists a positive correlation between the dependent variable (GDP) and independent variable (bank credit, Interest rate/Lending rate, inflation rates).

study:

However, the following null hypotheses were formulated to guide this

i. Credit to manufacturing sector has no significant effect on real gross domestic product in Nigeria;

ii. Credit to service sector has no significant effect on real gross domestic product in Nigeria;

iii. There is no significant relationship between credit to general commerce and real gross domestic product in Nigeria;

iv. There is no causal relationship between credit to production sector, credit to general commerce, and real gross domestic product in Nigeria.

\section{Methodology}

This research work employed the quantitative research technique because the study utilized numerical data. However, ex-post facto research design was adopted to examine the effect of bank credit on economic growth in Nigeria. This is considered suitable because the study employed historical non-manipulative data.

This research work made use of secondary sources of data which were obtained from Central Bank of Nigeria Statistical Bulletin. The data ranged from 1981 to 2017. For the purpose of examining the effect of the independent variables (proxy as Credit to Manufacturing Sector, Credit to General Commerce and Credit to Agricultural Sector) on Real Gross Domestic Product, the study employs multiple regression model.

According to McKinnon (1973) and Shaw (1973), economic growth is dependent on financial sector development. Thus, the relationship between finance and growth can be augmented from the McKinnon (1973) and Shaw (1973) model given as:

$\mathrm{RGDP}=f(\mathrm{CMS}, \mathrm{CGC}, \mathrm{CAS})$

$\mathrm{RGDP}_{\mathrm{t}}=\mathrm{B}_{0}+\mathrm{B}_{1} \mathrm{CMS}_{\mathrm{t}}+\mathrm{B}_{2} \mathrm{CGC}_{\mathrm{t}}+\mathrm{B}_{3} \mathrm{CAS}_{\mathrm{t}}+\mathrm{e}_{\mathrm{t}}$

Where:

RGD $=$ Real Gross Domestic Product

CMS $=$ Credit to Manufacturing Sector

$\mathrm{CGC}=$ Credit to General Commerce

$\mathrm{CAS}=$ Credit to Agricultural Sector 
$B_{0}=$ Constant Term

$B_{1}-B_{3}=$ Coefficient of Parameters

$e=$ Error Term

$t=$ Time subscript

\section{A Priori Expectation}

Theoretically, the flow of bank credit to different sectors of the economy is expected to exact positive and significant effect on economic growth. Thus, Credit to Manufacturing Sector, Credit to General Commerce, and Credit to Agricultural Sector are expected to influence Real Gross Domestic Product positively and significantly in the economy.

\section{Method of Data Analysis}

This study employed Augmented Dickey Fuller (ADF) and Philip Perron unit root test to test the stationarity of the variables to overcome the problems of spurious regression often associated with non-stationary time series data. It is, thus, reasonable to test for the presence of a unit root in the series using the following model. Thus:

$\Delta \mathrm{y}_{\mathrm{t}}=\alpha_{\mathrm{o}}+\mathrm{Yti}+\alpha 2 \mathrm{t}+\Sigma \beta \mathrm{j} \Delta \mathrm{yt}-\mathrm{I}+\mathrm{e}_{\mathrm{t}}$

Where $y$ is the series and $t$ the trend factor; $\alpha 0$ is the constant term, $e_{t}$ is the stochastic error term, and $\beta$ the lag length. The Augmented Dickey Fuller Test unit root test is employed to test the stationarity level of the series to determine the order of integration of the variables. Since the variables employed in the study are all stationary at first difference, long-run relationship was conducted using Johansen Co-integration Technique.

Furthermore, in order to test the existence of long-run relationship among the variables adopted in this study, co-integration test was conducted using Johansen Co-integration Test. This is necessary due to the non-stationarity of the variables of macroeconomic variables employed in the study. Johansen's methodology, which was expressed as a vector autoregression (VAR) of order $P$, is given by:

$y t=u+A 1 y t-1+\ldots \ldots . .+A p y t-p+\varepsilon_{t}$

Where $y t$ is an $n 1$ vector of innovations.

The study employed Error Correction Model in order to examine short run effect of Credit to Manufacturing Sector, Credit to General Commerce and Credit to Agricultural Sector on Real Gross Domestic Product. This approach takes into account the short-term adjustments of the variables as well as the speed of adjustment of the coefficients. It therefore measures the speed at 
which real gross domestic product will revert to its equilibrium following a short term shock to each of them.

The VECM specification has the following form:

$\mathrm{y}_{\mathrm{t}}=\infty_{0}+\mathrm{y}_{\mathrm{t}-1}+\mathrm{x}_{\mathrm{t}}+\mathrm{ECT}_{\mathrm{t}-1}+\mathrm{E}_{\mathrm{t}}$

Where $y_{t}$ represents the dependent variable, $y_{t-1}$ represents the first period lag of the dependent variable, $x_{t}$ represents the independent variable. ECT is given as Error Correction Term and E represents the error term.

Finally, Pairwise Granger Causality was employed to determine the direction of causality among Credit to Manufacturing Sector, Credit to General Commerce, and Credit to Agricultural Sector on Real Gross Domestic Product which is given as:

$\Delta \mathrm{RGDP}_{\mathrm{t}}=\beta 0+\gamma \mathrm{i} \Sigma \Delta \mathrm{iCMS}_{\mathrm{t}-\mathrm{i}}+\gamma \mathrm{j} \Sigma \Delta \mathrm{jCGC}_{\mathrm{t}-\mathrm{j}}+\gamma \mathrm{k} \Sigma \Delta \mathrm{kCAS}_{\mathrm{t}-\mathrm{k}}+v \mathrm{t}$

(6)

\section{Data Analysis and Interpretation of Results}

Table 1: Descriptive Statistics

\begin{tabular}{|l|c|c|c|c|}
\hline & RGDP & CMS & CAS & CGC \\
\hline Mean & 32749.95 & 460.3897 & 108.3011 & 128.1425 \\
\hline Median & 22449.41 & 115.7599 & 33.26410 & 25.30740 \\
\hline Maximum & 69023.93 & 2215.741 & 528.2438 & 1045.192 \\
\hline Minimum & 13779.26 & 2.659800 & 0.590600 & 0.107100 \\
\hline Std. Dev. & 18889.20 & 643.3481 & 160.8364 & 312.0566 \\
\hline Skewness & 0.801592 & 1.454539 & 1.646717 & 2.505848 \\
\hline Kurtosis & 2.141006 & 4.022203 & 4.319621 & 7.332858 \\
\hline Jarque-Bera & 5.099938 & 14.65760 & 19.40666 & 67.66491 \\
\hline Probability & 0.078084 & 0.000656 & 0.000061 & 0.000000 \\
\hline Observations & 37 & 37 & 37 & 37 \\
\hline
\end{tabular}

Source: Author's Computation, 2018

Table 1 presents the result of the descriptive statistics for the macroeconomic variables employed in this study. The result of the Jarque Bera test indicated that only real gross domestic product is normally distributed. The result further shows that real gross domestic product has higher variation when compared with credit to manufacturing sector, credit to agricultural sector, and credit to general commerce given larger maximum and minimum values of 69023.93 and 13779.26. The standard deviations for the variables indicated higher deviations of the data from their mean values.

Furthermore, the result indicated that the variables' real gross domestic product, credit to manufacturing sector, credit to agricultural sector, and credit to general commerce are positively skewed. The Kurtosis test showed that credit to manufacturing sector, credit to agricultural sector, and credit to general commerce are leptokurtic, while real gross domestic product is platykurtic. 
Table 2: Correlation Matrix

\begin{tabular}{|l|c|c|c|c|}
\hline & RGDP & CMS & CAS & CGC \\
\hline RGDP & 1.000000 & & & \\
\hline CMS & 0.205756 & 1.000000 & & \\
\hline CAS & 0.242810 & 0.386460 & 1.000000 & \\
\hline CGC & 0.252555 & 0.534762 & 0.542064 & 1.000000 \\
\hline
\end{tabular}

Source: Researchers' Computation, 2019

The result of the correlation matrix is represented in Table 2 and it shows that the independent variables are weakly and imperfectly correlated with real gross domestic product.

The results revealed that credit to manufacturing sector, agricultural sector, and credit to general commerce have positive and weak correlation with real gross domestic product in Nigeria. The implication of these findings is that an increase in bank credit to important sectors of the economy like manufacturing sector, agricultural sector, and general commerce will have positive effect on the growth of the economy which is in line with the theoretical expectations.

\section{Unit Root Test}

Table 3: ADF Unit Root Test at Level and First Differences

\begin{tabular}{|l|l|l|l|l|l|l|l|}
\hline \multicolumn{3}{|c}{ Level Form } & First Differences \\
\hline Variables & T-stat & $\begin{array}{l}\text { 5\% Critical } \\
\text { Value }\end{array}$ & P-value & T-stat & $\begin{array}{l}\text { 5\% Critical } \\
\text { Value }\end{array}$ & P-value & $\begin{array}{l}\text { Order of } \\
\text { Int. }\end{array}$ \\
\hline RGDP & 0.032145 & 2.948404 & 0.9553 & 3.339751 & 2.948404 & 0.0205 & $1(1)$ \\
\hline CMS & 0.963167 & 3.540328 & 0.9368 & 4.736265 & 3.544284 & 0.0029 & $1(1)$ \\
\hline CAS & 2.366505 & 3.540328 & 0.3898 & 6.865833 & 3.544284 & 0.0000 & $1(1)$ \\
\hline CGC & 3.504029 & 3.540328 & 0.0540 & 8.840354 & 3.544284 & 0.0000 & $1(1)$ \\
\hline
\end{tabular}

Source: Researchers' Computation, 2019

Table 3 shows the result of the Augmented Dickey Fuller unit root test at level and first difference. The unit root test of the variables is necessary to avoid the problem of spurious regression and to determine the order of integration of the variables.

The Table shows that the variables employed in the study, namely, real gross domestic product, credit to manufacturing sector, credit to agricultural sector, and credit to general commerce, are characterized with unit root problem at each level because the test statistics of the variables are less than the critical value 5\% significance level. Thus, the null hypothesis of unit root is accepted for all the variables. Hence, the variables are subject to unit root using Augmented Dickey Fuller test at first difference. However, the variables, real gross domestic product, credit to manufacturing sector, credit to agricultural sector, and credit to general commerce are free from unit root tangle at first difference since the T-statistics for each variable is greater than 
the respectively critical value and high significance at 5\%. Thus, the null hypothesis of unit root is rejected for real gross domestic product, credit to manufacturing sector, credit to agricultural sector, and credit to general commerce at first difference.

Table 4: Philip Perron Unit Root Test at Level and First Differences

\begin{tabular}{|l|l|l|l|l|l|l|l|}
\hline \multicolumn{3}{|c}{ Level Form } & \multicolumn{1}{l|}{ First Differences } \\
\hline Variables & T-stat & $\begin{array}{l}\mathbf{5 \%} \text { Critical } \\
\text { Value }\end{array}$ & P-value & T-stat & $\begin{array}{l}\text { 5\% Critical } \\
\text { Value }\end{array}$ & P-value & $\begin{array}{l}\text { Order } \\
\text { of Int. }\end{array}$ \\
\hline RGDP & 0.857782 & 2.945842 & 0.9937 & 3.179804 & 2.948404 & 0.0298 & $1(1)$ \\
\hline CMS & 5.188201 & 2.945842 & 1.0000 & 5.731892 & 2.948404 & 0.0000 & $1(1)$ \\
\hline CAS & 2.624741 & 2.945842 & 1.0000 & -6.917997 & 2.948404 & 0.0000 & $1(1)$ \\
\hline CGC & 0.291249 & 2.945842 & 0.9165 & 6.679620 & 2.948404 & 0.0000 & $1(1)$ \\
\hline
\end{tabular}

Source: Researchers' Computation, 2019

Table 4 reveals the PP unit root test for real gross domestic product, credit to manufacturing sector, agricultural sector, and to general commerce at first difference. It shows that real gross domestic product, credit to manufacturing sector, credit to agricultural sector, and credit to general commerce are free from unit root tangle at first difference since the T-statistics for each variable is greater than the respectively critical value and high significance at $5 \%$. Thus, the null hypothesis of unit root is rejected for real gross domestic product, credit to manufacturing sector, credit to agricultural sector, and credit to general commerce at first difference.

\section{Co-Integration Result}

Table 5: Unrestricted Co-integration Rank Test (Trace)

\begin{tabular}{|l|c|c|c|}
\hline $\begin{array}{l}\text { Hypothesized } \\
\text { No. of CE(s) }\end{array}$ & $\begin{array}{c}\text { Trace } \\
\text { Statistic }\end{array}$ & $\begin{array}{c}\mathbf{0 . 0 5} \\
\text { Critical Value }\end{array}$ & Prob. $* *$ \\
\hline None $*$ & 88.31004 & 47.85613 & 0.0000 \\
\hline At most $1 *$ & 52.16364 & 29.79707 & 0.0000 \\
\hline At most 2 $*$ & 23.84830 & 15.49471 & 0.0022 \\
\hline At most 3 $*$ & 4.438935 & 3.841466 & 0.0351 \\
\hline
\end{tabular}

Table 5 presents the result of the co-integration test between real gross domestic product, credit to manufacturing sector, credit to agricultural sector, and credit to general commerce using Johansen Co-integration test. The Trace Statistic shows that there are four co-integrating vectors among the variables since the trace statistics value are greater than the critical values at 0.005 critical value. Thus, the null hypostasis of no long-run relationship between real gross domestic product, credit to manufacturing sector, credit to agricultural sector, and credit to general commerce is rejected. 
Table 6: Unrestricted Co-integration Rank Test (Maximum Eigenvalue)

\begin{tabular}{|l|c|c|c|}
\hline $\begin{array}{l}\text { Hypothesized } \\
\text { No. of CE(s) }\end{array}$ & $\begin{array}{c}\text { Max-Eigen } \\
\text { Statistic }\end{array}$ & $\begin{array}{c}\mathbf{0 . 0 5} \\
\text { Critical Value }\end{array}$ & Prob.** \\
\hline None $*$ & 36.14641 & 27.58434 & 0.0031 \\
\hline At most $1 *$ & 28.31533 & 21.13162 & 0.0041 \\
\hline At most $2 *$ & 19.40937 & 14.26460 & 0.0070 \\
\hline At most $3 *$ & 4.438935 & 3.841466 & 0.0351 \\
\hline
\end{tabular}

Source: Researchers' Computation, 2019

Table 6 presents the result of Maximum Eigenvalue Johansen Cointegration between real gross domestic product, credit to manufacturing sector, credit to agricultural sector and credit to general commerce. The results reveals that there is co-integrating vectors among the variables as revealed by the Max-Eigen Statistics which are greater than the critical values at 5\% level of significance. This implies that there is long-run relationship between real gross domestic product, credit to manufacturing sector, credit to agricultural sector, and credit to general commerce.

Interpretation of Model Results

Table 7: Error Correction Model Dependent Variable: D(RGDP)

\begin{tabular}{|c|c|c|c|}
\hline Variables & Coefficient & t-Statistic & Prob. \\
\hline ECT(-1) & -0.073379 & -2.846113 & $0.0080 * *$ \\
\hline$\triangle($ RGDP(-1)) & 0.847355 & 7.699022 & $0.0000 * *$ \\
\hline$\triangle(\mathrm{CMS})$ & 3.475268 & 2.347085 & $0.0260 * *$ \\
\hline$\triangle(\mathrm{CAS})$ & 9.982209 & 2.049551 & $0.0495 * *$ \\
\hline$\widehat{(C G C)}$ & -2.043996 & -1.711974 & 0.0976 \\
\hline $\mathrm{C}$ & -58.55266 & -0.235816 & 0.8152 \\
\hline R-squared & 0.707675 & & \\
\hline Adjusted R-squared & 0.657274 & & \\
\hline F-statistic & 14.04090 & & \\
\hline Prob. (F-statistic) & 0.000001 & & \\
\hline Durbin-Watson stat & 2.192839 & & \\
\hline
\end{tabular}

Source: Researchers' Computation, 2019

Table 7 shows the result of the Error Correction model to establish the dynamic short-run effect of credit to manufacturing sector, credit to agricultural sector, and credit to general commerce on real gross domestic product in Nigeria.

The ECM result shows that the first period lag of real gross domestic product has positive and significant effect on current gross domestic product in Nigeria with a coefficient of 0.847355 , which implies that increase in productivities in the previous period will enhance productions in the current period in Nigeria. The implication of this result is that the economy will enjoy higher productivity in terms of real gross domestic annually, as productivities increased in the previous years. 
Furthermore, the result reveals that credit to manufacturing has positive and significant effect on real gross domestic product in Nigeria. The coefficient of credit to manufacturing is given as 3.475268. This implies that the more credit flows to the manufacturing sector from commercial banks, real gross domestic will increase by 3.475268 - which is in line with the a priori expectation.

Similarly, the result shows that credit to agricultural sector has positive and significant effect on real gross domestic product in Nigeria with a coefficient value of 9.982209 , which is highly significant at $5 \%$. This implies that, as credit to agricultural sector increase by one unit, real gross domestic product will increase by 9.982209 . The implication of this finding is that the more banks lend to the agricultural sector, the more the Nigerian economy experiences higher productivities through increase in the contribution of the agricultural sector to the gross domestic product.

However, credit to general commerce has negative and insignificant effect on real gross domestic product in Nigeria. The coefficient of credit to general commerce is given as -2.043996 , which is insignificant at $5 \%$, and this implies that a unit increase in credit to general commerce will lead to a 2.043996 fall in real gross domestic product in Nigeria.

Finally, the Error Correction Mechanism has a negative and significant value of -0.073379 which follows theoretical expectation. The significance of the Error Correction Mechanism affirms the existence of long-run relationship between the variables and that some adjustments take place within the current period based on the disequilibrium of the previous periods for each model at a speed of $7.3 \%$.

The result of Error Correction Model shows an Adjusted R-squared of 0.657274 . This implies that $65 \%$ variations in real gross domestic product are accounted for by the explanatory variables namely credit to manufacturing sector, credit to agricultural sector, and credit to general commerce on real gross domestic product.

The result shows that the Durbin-Watson statistic reveals a value of 2.192839 which implies that there is no problem of autocorrelation in the regression residual because the Durbin-Watson statistic value is within the acceptance region of 1.5 and 2.5 .

This study employed F-statistic in order to test the overall significance of the regression. The F-statistic which gives a value of 14.04090, which is significant at $5 \%$ given a probability value of 0.000001 , implies that credit to manufacturing sector, credit to agricultural sector, and credit to general commerce have significant effect on gross domestic product in Nigeria. 
Table 8: Pairwise Granger Causality Tests

\begin{tabular}{|l|c|c|c|c|}
\hline Null Hypothesis: & Obs & F-Statistic & Prob. & Result \\
\hline & 35 & & & Independent Relationship \\
CMS does not Granger Cause RGDP & & 1.82079 & 0.1793 & \\
RGDP does not Granger Cause CMS & & 3.28085 & 0.0515 & \\
\hline CAS does not Granger Cause RGDP & 35 & 3.07999 & 0.0607 & Unidirectional Relationship \\
RGDP does not Granger Cause CAS & & 5.74591 & 0.0077 & \\
\hline CGC does not Granger Cause RGDP & 35 & 6.15532 & 0.0058 & Bi-directional Relationship \\
RGDP does not Granger Cause CGC & & 4.17840 & 0.0251 & \\
\hline
\end{tabular}

Source: Researchers' Computation, 2019

The result of the Pairwise granger causality tests is presented in Table 8 . The result revealed that there is independent relationship between credit to manufacturing sector and real gross domestic product, and that implies that there is no causality between credit to manufacturing sector and real gross domestic product.

Also, it was found that there is a unidirectional relationship between credit to agricultural sector and real gross domestic product. It was revealed that causality runs from real gross domestic product to credit to agricultural sector without causality running from credit to agricultural sector to real gross domestic product. Finlay, the result revealed that there is a bidirectional relationship between credit to general commerce and real gross domestic product.

\section{Discussion of Findings}

This study examines the disaggregated effect of bank credit on economic growth in Nigeria. The study employs Augmented Dickey Fuller for unit root testing of the variables and it was established that credit to manufacturing sector, to agricultural sector, general commerce, and real gross domestic product were not stationary at level but were stationary when tested at first difference.

The study used Johansen Co-integration Test in order to establish the long-run relationship between credit to manufacturing sector, agricultural sector, general commerce, and real gross domestic product. Based on the result of the trace statistic and max-egin statistic, there were four co-integrating vectors among the variables which implies that there is long-run relationship between credit to manufacturing sector, credit to agricultural sector, credit to general commerce, and real gross domestic product. This result is supported by that of Bakare et al. (2015), that there is long-run relationship between bank credit and economic growth.

The Error Correction Model indicated that credit to manufacturing sector has positive and significant effect on real gross domestic product in Nigeria, which implies that the more credit flows to the manufacturing sector 
from commercial banks, there will be an increase in real gross domestic in the economy. This finding is in line with the result of Adewole, et al. (2018), who established positive relationship between bank credit to real sector and economic growth in Nigeria. However, the result contradicted that of Makinde (2016) who found a negative relationship between credit to manufacturing sector and gross domestic product.

Similarly, the result showed that credit to agricultural sector has positive and significant effect on real gross domestic product in that it indicated that as credit to agricultural sector increases, there will be an increase in real gross domestic product in Nigeria. This result is supported by the empirical finding of Makinde (2016) that there is positive relationship between credit to agricultural sector and economic growth.

Finally, the findings revealed that credit to general commerce has negative and insignificant effect on real gross domestic product in Nigeria, thereby implying that an increase in credit to general commerce will lead to a fall in real gross domestic product in Nigeria. The outcome of the study was at variance with the result of Akujuobi and Nwezeaku (2015) that credit to general commerce has negative effect on economic growth.

\section{Conclusion and Recommendations}

Commercial banks play a significant role in the growth and development process of an economy. Banks ensure the intermediation of funds and credits among economic agents in the economy. However, the credit granting function is of great importance in the economy because effective and efficient credit granting does not only increase banks revenue but enhances economic productivities and growth.

Thus, this study examined the effect of bank credit on economic growth in Nigeria by disaggregating bank credit into credit to manufacturing sector, credit to agricultural sector, and credit to general commerce, and also examining their effect on economic growth in Nigeria. However, based on research findings, the study concluded that bank credit to different sectors of the economy plays a significant role in promoting economic growth in Nigeria. The study thus recommends that banks should ensure the flow of more credits to the manufacturing sector in order to ensure a bidirectional relationship between credit to the sector and economic growth.

Also, there is need for banks to prioritize lending to the agricultural sector given the positive role of credit to the sector on economic growth, as this would lead to the realizing of the full potentials of the sector. Also, more credits should flow to small farmers in the rural areas via adequate monitoring because these small farmers form the main bedrock of the agricultural sector.

Given the negative relationship between credit to general commerce and economic growth, there is need for increase of credits to sectors such as 
export, services, and other related secretors in order to stimulate the contribution of the sector to economic growth.

Finally, monetary authorities should formulate policies to ensure that more funds will be available to the banking sector. This is because more funds and high liquidity position in the bank sector increase banks' ability to grant credit to important sectors in the economy.

\section{Study Limitation and Suggestion for Future Studies}

This study is limited by financial resources through which an extended work could be done through the effect on bank credit on sectoral performance in Nigeria. Thus, future studies should consider exploring the effect of bank credit on sectoral performance via comparative analysis for adequate findings and policy recommendations.

\section{References:}

1. Abubakar, A. \& Gani, I.M. (2013). Impact of banking sector development on economic growth: Evidence from Nigeria. Journal of Business Management \& Social Sciences Research, 2(4), 47- 59.

2. Adeniyi, O.M. (2006). Bank credit and economic development in Nigeria: A Case Study of Deposit Money Banks. Jos University of Jos.

3. Adenugba, A.A. (2015). Banking system credit as an instrument of economic growth in Nigeria (1983 - 2012). European Journal of Business, Economics and Accountancy, 3(7), 1-23.

4. Adewole, J.A., Akinmulegun, S.O., Akinde, J.A. \& Popoola, M.A. (2018). Deposit money bank credit and economic growth in Nigeria (2006-2015). IJARIIE, 4(3), 1711-1720.

5. Ajayi, D.D. (2000). The determinants of the volume of production subcontracting in Nigeria. Nigeria Journal of Economic and Social Studies (NJESS), 42(1), 1-11.

6. Ajayi, D.D. (2000). The determinants of the volume of production subcontracting in Nigeria. Nigeria Journal of Economic and Social Studies (NJESS), 42(1), 1-11.

7. Akpansung, A.O. \& Babalola, S. J. (2012). Banking sector credit and economic growth in Nigeria: An empirical investigation. CBN Journal of Applied Statistics, 2(2), 51 -62.

8. Akujuobi, A.B.C. \& Nwezeaku, N.C. (2015). Bank lending activities and economic Ademu development in Nigeria: An empirical investigation. International Proceedings of Economics Development and Research, 85, 57-67.

9. Aliero, H.M., Abdullahi, Y.Z. \& Adamu, N. (2013). Private sector credit and economic growth nexus in Nigeria: An Autoregressive 
Distributed Lag Bound Approach. Mediterranean Journal of Social Sciences, 4(1), 23-43.

10. Anthony, O. (2012). Banking savings and bank credits in Nigeria: Determinants and impact on economic growth: International Journal of Economics and Financial Issues, 2(3), 357-372.

11. Aretis, P., Baddeley, M. \& \& McCombie, J. (2007). Economic growth: New directive in theory and policy. Cheltenham: Edward Elgar Publishing Limited.

12. Artelaris, A., Antonios, D., Mark, N. \& Edwin, G. (2007). DMB credit market development and economic growth: An empirical analysis for Ireland. European Research Studies, 13(4), 3-18.

13. Asamoah, G.N. (2008). The impact of the financial sector reforms on savings, investments and growth of gross domestic product (GDP) in Ghana'. International Business, and Economic Research Journal, 7(10), 73-84.

14. Azeez, B.A. \& Oke, M.O. (2012). A time series analysis on the effect of banking reforms on Nigeria's economic growth. International Journal of Economics and Research, 3(4), 26-37.

15. Bakare, I.A.O., Isaac, A.J. \& Samuel, K.H. (2015). To what extent does banks' credit stimulate economic growth? Evidence from Nigeria. JORIND, 13(1), 128-139.

16. Central Bank of Nigeria (2007). Annual Report Abuja Research Department.

17. Ekpenyong, D.B. \& Aecha I.A. (2011). Banks and economic growth in Nigeria. European Journal of Business and Management, 3(4), 155166.

18. Goldsmith, R. W. (1969). Financial structure and development. New Haves CT: Yale University Press.

19. Gregory, A.W. \& Hansen, B.E. (1996a). Residual-based tests for cointegration in models with regime shifts. Journal of Econometrics, 70, 99-126.

20. Igyo, A.J., Simon, J. \& Lorlumun, A.P. (2016). Deposit money banks' credit and investment drive of developing economies: Empirical evidence from Nigeria. Asian Journal of Agricultural Extension, Economics \& Sociology, 11(1), 1-12.

21. IMF (2001). Theories of Economic Growth-Neo-Classical. Retrieved on April 19, 2010 from www.google.com.

22. Iwedi, M. \& Onuegbu, O. (2014). Credit risk and performance of selected deposit money banks in Nigeria: An empirical investigation. European Journal of Humanities and Social Science, 31(1), 1684 1694. 
23. Jhingan, M.L. (2006). The economics of development and planning. (38th Ed). Delhi: Virnda Publication (P) Ltd.

24. John, E.E. \& Terhemba, I.P. (2016). Commercial bank credit and manufacturing sector output in Nigeria. Journal of Economics and Sustainable Development, 7(16), 189-196.

25. John, E.E. \& Terhemba, I.P. (2016). Commercial bank credit and manufacturing sector output in Nigeria. Journal of Economics and Sustainable Development, 7(16), 189-196.

26. Makinde, A.H. (2016). Implications of commercial bank loans on economic growth in Nigeria (1986-2014). Journal of Emerging Trends in Economics and Management Sciences, 7(3), 124-136.

27. Marshal, I., Solomon, I.D. \& Onyekachi, O. (2015). Bank domestic credits and economic growth nexus in Nigeria (1980-2013). International Journal of Finance and Accounting, 4(5), 236-244.

28. Mckinnon, R.I. (1973). Money and Capital in Economic Development, Brookings Institution; Washington D.C.

29. Mushtaq, S. (2016). Causality between bank's major activities and economic growth: Evidences from Japan. Munich Personal RePEc Archive, 69052, 1-11.

30. Nwakanma, P.C., Nnamdi, I.S. \& Omojefe, G.O. (2014). Bank credits to the private sector: Potency and Relevance in Nigeria's Economic Growth Process. Accounting and Finance Research, 3(2), 23-35.

31. Nwaru, N.M \& Okorontah, C.F. (2014). Banks' credit as an instrument of economic growth in Nigeria. International Journal of Business \& Law Research, 2(2), 25-33.

32. Nzotta, S. M. (2002). Money, banking and finance: Theory and practice. (2ndEd). Owerri: Hudson Jude Nigerian Publishers.

33. Obamuyi, T.M., Edun T.A. \& Kayode O.F. (2011). Bank lending, economic growth and the performance of the manufacturing sector in Nigeria. European Scientific Journal, 8(3).

34. Obradovic, S. \& Grbic, M. (2015). Causality relationship between financial intermediation by banks and economic growth: Evidence from Serbia. Prague Economic Papers, 24(1), 60-72.

35. Odufuye, B.M. (2017). Bank credits and its impact on Nigerian economy growth. International Journal of Development Strategies in Humanities, Management and Social Sciences, 7(3), 39-52.

36. Ogbonna, G.N. \& Appah, E. (2012). Impact of tax reforms and economic growth of Nigeria: A time series analysis. Current Research Journal of Social Sciences, 4(1), 13 - 33.

37. Ogege, S. \& Shiro, A.A. (2013). Does depositing money in bank impact economic growth? Evidence from Nigeria. African Journal of Business Management, 7(3), 196- 205. 
38. Ogunmuyiwa, M.S., Okunneye, B.A. \& Amaefule, J.S. (2017). Bank credit and growth of the manufacturing sector nexus in Nigeria: An ARDL approach. Euro Economica, 2(36), 62-72

39. Ogunmuyiwa, M.S., Okunneye, B.A. \& Amaefule, J.S. (2017). Bank credit and growth of the manufacturing sector nexus in Nigeria: An ARDL approach. Euro Economica, 2(36), 62-72

40. Olowofeso, E.O., Adeleke, A.O. \& Udoji, A.O. (2015). Impact of private sector credit on economic growth in Nigeria. CBN Journal of Applied Statistics, 6(2), 81-101.

41. Oluitan, R.O. (2012). Bank credit and economic growth: Evidence from Nigeria. International Business and Management, 5(2), 102-110.

42. Ono, S. (2017). Financial development and economic growth nexus in Russia. Russian Journal of Economics, 3, 321-332.

43. Pandey, I.M. (2006). Financial management: Credit policy. (9th Ed.,) New Delhi, Vikas Publishing House PVT LTD.

44. Schumpeter, J. A. (1934). The Theory of Economic Development. Cambridge, Mass: Havard University Press.

45. Shaw, E. S. (1973). Financial Deepening in Economic Development. Oxford University Press, New York.

46. Shittu, A.I. (2012). Financial intermediation and economic growth in Nigeria. British Journal of Arts and Social Sciences, 4(2), 164-179.

47. Sipahutar, M.A., Oktaviani, R., Siregar, H. \& Juanda, B. (2016). Effect of credit on economic growth, unemployment and poverty. Jurnal Ekonomi Pembangunan, 17(1), 37-49.

48. Ugoani, J.N. (2013). Power of bank credit on economic growth: A Nigerian perspectives. International Journal of Financial Economics (IJFE), 385(3), 93-102.

49. Uremadu, S.O. (2005). Determinants of banking system credit to the Nigerian economy in a liberalized financial system: An empirical analysis. BIJAR, BUK Kano.

50. Wang, Y., Li, X., Abdou, H.A. \& Ntim, C.G. (2015). Financial development and economic growth in China. Investment Management and Financial Innovations, 12(3), 8-18.

51. Yakubu, Z. \& Affoi, A.Y. An analysis of commercial banks' credit on economic growth in Nigeria. Current Research Journal of Economic Theory, 6(2), 11-15. 